\title{
HIGHWAY ALIGNMENT OPTIMIZATION BY USING COST AND SAFETY CRITERIA
}

\author{
Seyed Mahdi Sajjadi, Seyyed Amir Hossein Beheshty
}

Original scientific paper

Research on highway alignment optimization has been quite intensive over the last two decades. Determining the best candidate for highway alignment is one of the most complex highway design stages due to the different effects of various parameters. Hence, in the present study, Analytic Hierarchy Process technique is proposed to determine the best highway candidate with special focus on the cost and safety criteria. The methodology presented in the current research is not limited to the cost and safety criteria but can be extended to other criteria. This methodology is implemented on a case study region in north-western Iran, and therefore the cost and safety criteria are obtained for the case study conditions. The final result of the current paper indicates that the optimal highway candidate obtained with the proposed methodology can simultaneously meet all relative parameters in highway alignment optimization based on their impact.

Keywords: Analytic Hierarchy Process; cost category; safety parameter; the best highway candidate

Optimizacija trase autoceste pomoću kriterija troškova i sigurnosti

Izvorni znanstveni članak Istraživanje o optimizaciji trase državne ceste postalo je vrlo intenzivno u zadnja dva desetljeća. Određivanje najboljeg kandidata za trasu ceste jedan je od najsloženijih stadija u projektiranju ceste zbog različitih učinaka raznih parametara. Stoga se u ovom istraživanju predlaže metoda analitičkog hijerarhijskog procesa u svrhu određivanja najboljeg kandidata za cestu posebno usmjerena na kriterije troškova i sigurnosti. Metodologija predložena u ovom istraživanju nije ograničena na kriterije troškova i sigurnosti već se može proširiti i na ostale kriterije. Ta je metodologija primijenjena na istraživano područje na sjeverozapadu Irana te su kriteriji troškova i sigurnosti dobiveni za uvjete analiziranog slučaja. Konačni rezultat pokazuje da optimalni kandidat za cestu dobiven predloženom metodologijom može simultano zadovoljiti sve relevantne parametre u optimizaciji trase državne ceste na temelju njihovog utjecaja.

Ključneriječi: analitički hijerarhijski proces; najbolji kandidat za državnu cestu; parametar sigurnosti; troškovna kategorija

\section{Introduction}

A great deal of research effort has been made in recent years to develop methods of determining optimal highway candidates. So far, several extensive research works have been carried out to determine optimal alignment worldwide, which has led to the emergence of different models and algorithms. Some of the most important are: calculus of variations [1], network optimization [2], dynamic programming [3], genetic algorithm [4], and geographic information system [5]. All models that are presented for highway alignment optimization perform alignment optimization only by minimizing the total cost. Meanwhile, determining the best highway candidate is very complex and several parameters play a role besides cost, such as safety, constraint, social, environmental and so on.

Cost is one of the most important parameters in determining an optimal highway candidate. The cost parameter in highway alignment optimization is divided into direct and indirect costs. Indirect costs are paid by government and private sector investments (e.g., costs related to highway design, construction, maintenance, air and noise pollution, etc.), while direct costs are paid by highway users after highway operation (e.g., vehicle operating costs, lost time costs, toll and parking costs, etc.). In the routing stage of highway alignment there is not enough information about each highway candidate thus in the current research only indirect costs are considered. The four categories of indirect cost functions considered for provided example in this research are included length-dependent cost, structural cost, locationdependent cost and earthwork cost. The results of each cost category for a highway candidate can express the weight of that candidate as well as of every cost category.

Another significant parameter that plays an important role in highway alignment optimization is safety. Global statistics indicate that over one million people lose their lives in road accidents annually. According to the latest report by the World Health Organization (WHO), road injuries that lead to death are among the top 10 causes of death all over the world. The statistics provided by WHO indicate that around 1.3 million people died in road accidents in 2012 worldwide. A similar statistic shows that nearly 25000 people lose their lives in Iran annually in road accidents. According to studies conducted in Iran, the main causes of accidents are, respectively: human factors $(70 \%)$, road and environmental factors $(20 \%)$, and vehicle factors (10\%) [6]. Therefore, the effect of road and environmental factors is substantial in road accident occurrences in Iran. With correct routing and use of all effective parameters in determining the best highway candidates, such as compulsory points, seas, marshes, rivers, hydrology, geology, faults, landslides, etc., the rate of accidents can be reduced [7].

The current paper presents a new methodology for determining the best highway candidates using the Analytic Hierarchy Process technique with specific focus on the cost and safety parameters. Other criteria for highway optimization such as social, environmental and etc. are not in the scope of this research. The weight of each safety parameter relative to the others is obtained through questionnaires. However, the weight of each highway candidate based on every safety and cost parameter is obtained by extracting the safety and cost parameters from the highway candidates and then using a method defined in this paper. Finally, the weights 
obtained for cost and safety will be used in the AHP technique, after which the best highway candidate will be attained based on the provided methodology. The best candidate found according to the proposed methodology can meet all parameters used simultaneously. The cost and safety parameters investigated in the current paper are based on conditions in Iran and can be promoted for other territories.

\section{Cost category}

In this study, four cost function categories are considered and expanded, including: length-dependent cost, structural cost, location-dependent cost and earthwork cost. The calculated costs in this paper are estimated by assuming some of the parameters and approximating. These cost functions are merely used for determining the comparable weights of costs related to each highway candidate, which are required in the Analytic Hierarchy Process (AHP) technique. All cost categories used in this study are obtained for the case study region, which is located in northwest Iran between the Qeydar and Zarrin Rood cities. These cost categories can also be upgraded for other case studies.

\subsection{Length-dependent costs}

In this research, the concept of length-dependent costs entails costs that have a direct relationship with the decrease or increase of highway length and are divided into three categories as follows:

1. Pavement costs including sub-base, base and pavement surface

2. Costs related to signs and signals

3. Costs associated with safety and facilities such as guardrails, lighting systems, etc.

The main factor in the above-mentioned costs is highway length, although other factors are also involved in determining costs. For example, with increasing the highway candidate's length, costs associated with the highway will increase. Subsequently, additional details on each of these costs will be given.

\subsubsection{Pavement cost}

One of the costs associated with highway length includes the cost of preparing and implementing the subbase, base, surface and haul, which have a direct relation with the highway length. In the current research, the unit cost related to pavement is defined as upc. Therefore, the costs associated with highway pavement will be found with Eq. (1). In this research, the unit cost related to highway pavement for all highway candidates is assumed to be constant, because this cost is dependent on length, whereas the type and location of highway candidates have no effect on determining it.

$$
C_{l e n(p)}=L \times u p c,
$$

where: $C_{l e n(p)}$ - pavement cost related to length-dependent cost; upc - unit pavement cost; L - length of highway candidate.

\subsubsection{Costs related to signs and signals}

This type of cost is related to the cost of supplying and installing traffic signals and guide boards along highways. In this research, the unit cost related to signs and signals is denoted by usc. Therefore, the cost related to signs and signals on highways is obtained with Eq. (2). This cost is dependent on factors such as the highway's geometric design, road type and geographical conditions, etc. In this study, given that the general conditions of highway candidates are almost identical between two points, it is assumed that such costs are directly related to highway length and the unit cost is assumed to be constant for all candidates.

$C_{\text {len }(s)}=L \times u s c$,

where: $C_{\text {len(s) }}$ - signs and signals costs related to lengthdependent cost; usc - unit sign cost; $L$ - length of highway candidate.

\subsubsection{Costs associated with safety guard rails and facilities}

This type of cost is associated with the cost of supplying and installing middle highway guard rails as well as lighting systems along highways. In this research, the unit cost related to safety and facilities is defined by uic. Therefore, the costs associated with highway safety and facilities can be calculated using Eq. (3). This cost is directly related to the length of the highway candidate, thus uic can be fixed for all candidates.

$C_{\text {len(i) }}=L \times$ uic

where: $C_{l e n(i)}$ - safety guard rails and facility costs related to length-dependent cost; uic - unit installation cost; $L$ length of highway candidate.

The total cost related to the length of each highway candidate can be defined according to Eq. (4):

$T C_{\text {len }}=C_{\text {len }(p)}+C_{\text {len }(s)}+C_{\text {len }(i)}$.

\subsection{Location-dependent cost}

The final, location-dependent cost is associated with the unit cost of land with different applications and areas along the highway candidate (including land allocated for highway alignment and required highway margins). Based on different regulations, the necessary highway margins differ. For example, the Regulations for Geometric Design of Iran Roads [8] determined a width equal to 76 meters for highways (total width of highway including width of lanes and needed margin).

In terms of highway alignment being a function of point intersection (PI), location-dependent costs can be given by the following equation [9]:

$$
T C_{l o c}=\sum_{i=1}^{n l p} u c_{i} \times a f_{i},
$$


where: $T C_{l o c}$ - total location-dependent cost; $u c_{i}$ - unit cost of the $i^{\text {th }}$ land parcel in the study area; $a f_{i}$ - fractional area of the $i^{\text {th }}$ land parcel required for highway alignment; $n l p$ total number of land parcels in the study area.

Moreover, land parcels can be divided into two categories in terms of ownership type: (a) real ownership (personal), and (b) legal ownership (public or private organizations). The unit cost of each of the mentioned types of land parcel can be based on different factors as follows $[8,9]$ :

- Land use of land parcels, such as: commercial, residential, industrial, agricultural (farmland or gardens) and national land

- Land distance from the boundaries of the city or village.

Given the scope of this study, which is to determine the optimal highway candidate between two points (two centres of populations), land parcels located outside the boundaries of cities or villages are considered.

There are different conditions to determine the unit cost of land in various regions. Urbanism structures may come in different forms from country to country. For instance, in the country studied in this research (Iran) all land used for constructing a highway between two cities is divided into three categories: (1) Industrial land, (2) national land, and (3) agricultural land. Each of the three categories can be under the ownership of one of modes (a) or (b), meaning real or legal ownership as listed above. In the following an explanation for each land use abovementioned for case study region is provided:

(1) Industrial land

Today, industrial land for urbanism structures is usually located outside cities' boundaries and comprises industrial towns. In case of the study region, no highway candidate is permitted to pass through these areas. In other words, this kind of land parcels is considered as a constraint. Industrial land is normally owned by private sectors.

(2) National land

National land is typically under government ownership. In this research, the cost related to national land is assumed to be zero if it is not part of the constraints parameters, such as environmental or geographical constraints.

(3) Agricultural land

Various factors that are effective in determining the cost of agricultural land are: amount of water, fertility, distance to existing roads, regional climate, distance to the city boundaries, etc. In this study, only the effect of the land parcel's distance to the city boundary is considered.

Thus, according to the explanations in the three sections presented above, Eq. (5) can be upgraded to the following equation based on every case study condition:

$$
T C_{l o c}=\sum_{i=1}^{n g p} \alpha_{i} \times u g c \times A_{g i}+\sum_{i=1}^{n f p} \alpha_{i} \times u f c \times A_{f i},
$$

where: $u g c$ - unit cost of standard land parcel with garden land use located near the city boundary based on real estate agents; $u f c$ - unit cost of standard land parcel with farmland land use located near the city boundary based on real estate agents; $A_{g i}$ - fractional area of the $i^{\text {th }}$ land parcel with garden land use located in highway alignment regions; $A_{f i}$ - fractional area of the $i^{\text {th }}$ land parcel with farmland land use located in highway alignment regions; $\alpha_{i}$ - an index based on the case study conditions and the distance of the $i^{\text {th }}$ land parcel to the city boundary; $n g p$ number of garden land parcels; $n f p$ - number of farmland land parcels.

$\alpha_{i}$ can be obtained by using a questionnaire (asking real estate agents questions on the range of land parcel cost in the case study region). For example, for the present case study the following amounts were acquired: $\alpha_{i} \cong 1$ if land parcel is located less than 2 kilometres; $\alpha_{i} \cong$ 0.85 if land parcel is located between 2 kilometres and 5 kilometres from the city boundary; $\alpha_{i} \cong 0.75$ if land parcel is located more than 5 kilometres from the city boundary.

\subsection{Structural costs}

Structural cost is another effective cost in the selection of optimal highway candidates including cost related to bridges, tunnels, retaining walls, culverts, etc. This cost for various highway candidates may vary according to geographical situation and should be calculated separately for each candidate. This cost is generally divided into three major categories as follows:

1) Costs related to bridges

2) Costs related to tunnels

3) Costs related to retaining walls.

In the next sections, each cost related to structure will be investigated more comprehensively.

\subsubsection{Costs related to bridges}

Bridges are normally needed when crossing rivers, valleys or old roads. These regions as well as bridge dimensions can be identified using the GIS database. In accordance with the regulations on Iranian roads' geometric design [6] a bridge is defined as:

\section{- Bridge}

It is a structure that spans over 6 meters, which allows a path for passing over a waterway, valley, power transmission lines, railway, or old roads. The distance between bridge fulcrums along the bridge centre line is called the bridge span. In a multi-span bridge, the length of each span should be 3 meters or more.

In the current research, the unit cost related to bridge volume is denoted by $u b c$ and the total length of each bridge $\left(L_{b}\right)$ is obtained from the GIS database or other software. Eq. (7) shows the total cost related to bridges along highway candidates.

$C_{s t r(b)}=\sum_{j=1}^{s e g} L_{b(j)} \times u b c$

where: $C_{s t r(b)}$ - total bridge cost along a highway candidate; $L_{b(j)}$ - length of the $j^{\text {th }}$ bridge; $u b c$ - unit bridge 
cost based on bridge volume; seg - number of bridges along the highway alignment region.

\subsubsection{Costs related to tunnels}

In some cases, predicting tunnels along the studied candidate is logical and necessary. A tunnel may be selected along a highway candidate for reasons such as: economics, reduction of candidate highway length, road protection in snowy regions, landslide areas, avalanche risk, etc. On highways, tunnels are constructed as oneway and the number and width of lanes and road shoulders inside a tunnel are identical to those outside the tunnel [8]. Using the GIS database can help determine the position and length of tunnels along highway alignment areas. In the current research, the unit cost related to tunnel construction is given as utc and the total length of each tunnel $\left(L_{T}\right)$ is obtained from the GIS database or other software. Eq. (8) shows the total cost related to tunnels along highway candidates.

$$
C_{s t r(t)}=\sum_{j=1}^{s e g} L_{t(j)} \times u t c,
$$

where: $C_{s t r(t)}$ - total tunnel cost along a highway alignment region; $L_{t(j)}$ - length of the $j^{\text {th }}$ tunnel; $u t c$ - unit tunnel cost based on tunnel length; seg - number of tunnels along a highway alignment region.

\subsubsection{Costs related to retaining walls}

Retaining walls are used for soil motion control and overload of various structures on roads or at the foot of excavation and embankment. These structures are generally constructed in places where the groundwater level is high and the soil is poor. Retaining walls can be used depending on soil elevation, administrative constraints, type of facility located on the soil and climate conditions [8]. The location and dimensions of retaining walls can be determined using the GIS database or other software. In the current research, the unit cost related to constructing retaining walls is defined by $u w c$ and the total area of each retaining wall $\left(A_{w}\right)$ is obtained from the GIS database or other software. Eq. (9) shows the total cost related to retaining walls along highway alignment areas.

$$
C_{s t r(w)}=\sum_{j=1}^{s e g} A_{w(j)} \times u w c
$$

where: $C_{s t r(w)}$ - total retaining wall cost along highway alignment areas; $A_{w(j)}$ - area of the $j^{\text {th }}$ retaining wall; $u w c$ unit retaining wall cost; seg - number of retaining walls along highway alignment areas.

The total cost related to structures on highways can be defined according to Eq. (10):

$$
T C_{s t r}=C_{s t r(b)}+C_{s t r(t)}+C_{s t r(w)} .
$$

\subsection{Earthwork costs}

Earthwork costs include costs related to excavation, embankment and haul. So far, many methods have been proposed to calculate this cost. Two popular methods of calculating earthwork volume are (a) the trapezoidal method and (b) the average end area method. Although the trapezoidal method offers better precision, it increases the computational burden. For the planning phase, assessment with the average end area method is sufficient [12]. In the current study, the average end area method is also used to determine the earthwork volume of each candidate in AutoCAD Civil 3D software.

To determine the earthwork (embankment and excavation) volume, the grade line (or project line) of the highway candidate should initially be determined in order to satisfy the following factors:

- The volumes of excavation and embankment should be equal

- The allowable longitudinal slope should not be exceeded.

Therefore, various grade lines that satisfy the above factors can be obtained; in other words, the grade line is not unique, as it can be changed according to the situation. In the current study, only grade lines that can satisfy the maximum allowable slope are considered.

After determining the volume of earthwork for each candidate highway, the following equation can be used to find the earthwork cost. In this equation, it is assumed that cost related to haul is fixed for all candidates, and it is therefore ignored.

$C_{E}=V_{c} \times u c c+V_{f} \times u f c$,

where: $C_{E}$ - earthwork cost for each candidate $(\$) ; V_{c}$ total cut volume of each candidate; $V_{f}$ - total fill volume of each candidate; $u c c$ - unit cost of cut $\left(\$ / \mathrm{m}^{3}\right) ; u f c$ - unit cost of fill $\left(\$ / \mathrm{m}^{3}\right)$.

\subsection{Cost weights}

In the previous sections, four functions related to highway costs were presented and expanded based on the case study conditions. All of these cost functions are used in the current study in order to determine the weights of the cost categories for each highway candidate and weight of each cost category. Basically, these cost functions are for obtaining the weights of cost categories relative to each other (the weight of each cost category) as well as obtaining the weight of each candidate based on each cost category.

In this study, a method of determining the cost weights is suggested. To determine the AHP weight of each candidate based on each cost category, the cost of each defined candidate should be initially calculated using the provided cost functions. Afterward, the AHP weight of each candidate will be obtained based on the following chart: 


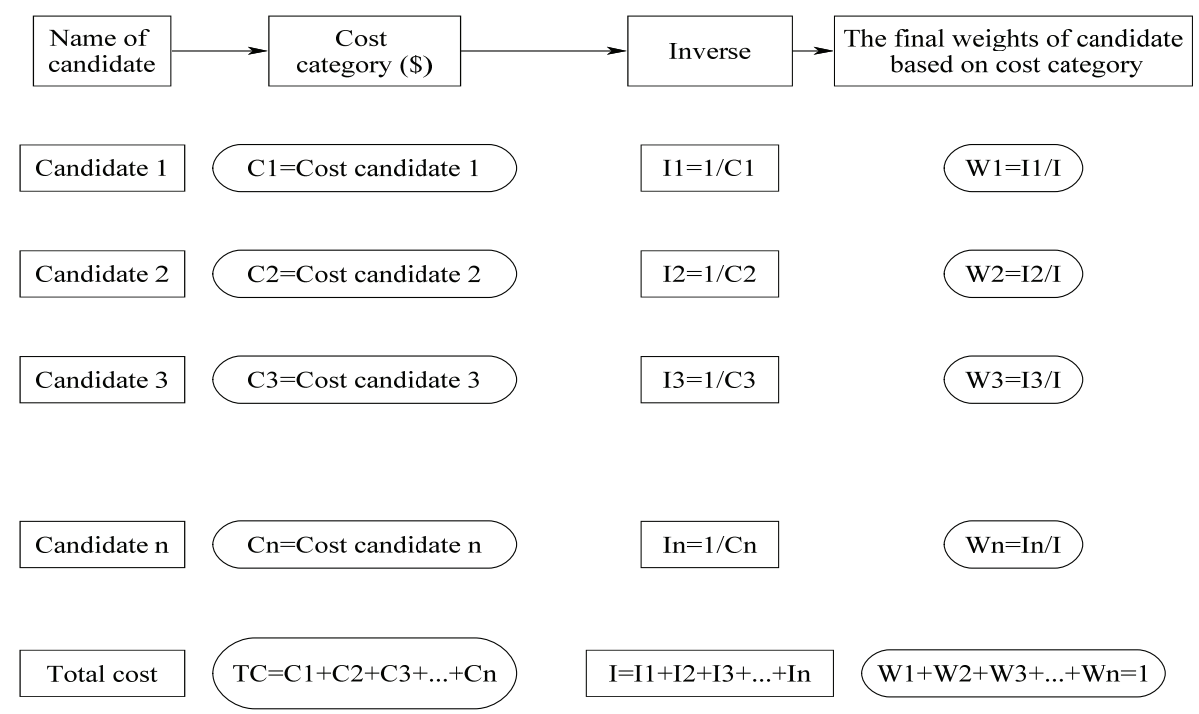

Figure 1 Flowchart for obtaining the weight of each candidate based on each cost category

The AHP weights of all highway candidates should be calculated using the above flowchart based on every cost category as investigated in previous sections. These weights will be applied to the process of determining the best highway candidate using the Analytic Hierarchy Process technique.

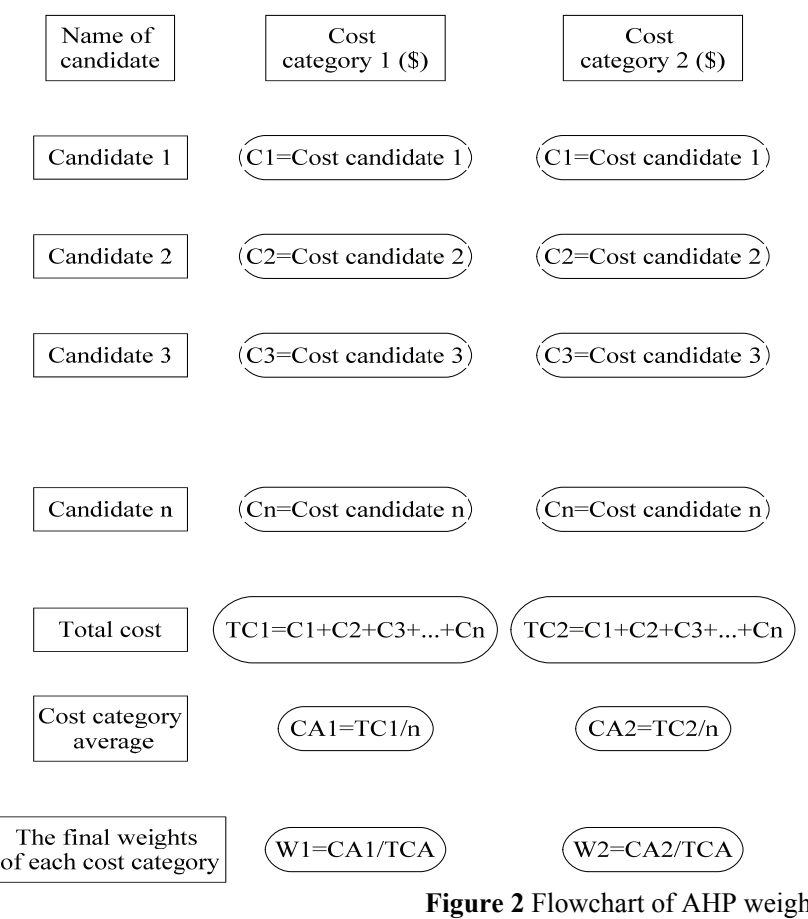

These cost categories' weights and cost weights of all highway candidates will be used in the process of determining the best candidate using the AHP technique.

\section{Safety parameters}

Several geometric characteristics of highway alignment can play an important role in reducing road accidents, e.g., horizontal curve, vertical curve, horizontal and vertical curve interference, direct path, tunnels, bridges, minimum radius of horizontal curve, etc. The
To determine the AHP weight of each cost category, the process shown in the flowchart in Fig. 2 can be used. To use this process, the average of each cost category (location-dependent cost, earthwork cost, lengthdependent cost and structural cost) needs to first be calculated for all candidates, after which the process below can be used. 
horizontal curves and the number of vertical curves. According to the importance of highway projects, the effective safety parameters to be used in determining the best highway candidate can be increasingly accurate. The weights of each safety parameter in the current study were obtained through questionnaires, which were developed based on the AHP technique. In this research, 15 participants attended, who had good experience in highway safety. They had a role in determining the weights of the safety parameters. Tab. 1 presents the final weights of the safety parameters obtained from the questionnaires.
Table 1 Final safety parameter weights based on the questionnaires

\begin{tabular}{|l|c|}
\hline \multicolumn{1}{|c|}{ Criteria Name } & AHP Weight \% \\
\hline Number of horizontal curve & 18.18 \\
\hline Number of vertical curve & 9.09 \\
\hline $\begin{array}{l}\text { Number of horizontal and vertical curve } \\
\text { interference }\end{array}$ & 72.73 \\
\hline
\end{tabular}

\subsection{Weight of each highway candidate based on each safety parameter}

To determine the weight of each highway candidate in terms of safety parameters, the following chart process can be employed. In this method, each safety parameter for each highway candidate needs to be first extracted, and then the weight of each candidate will be obtained using the following chart.

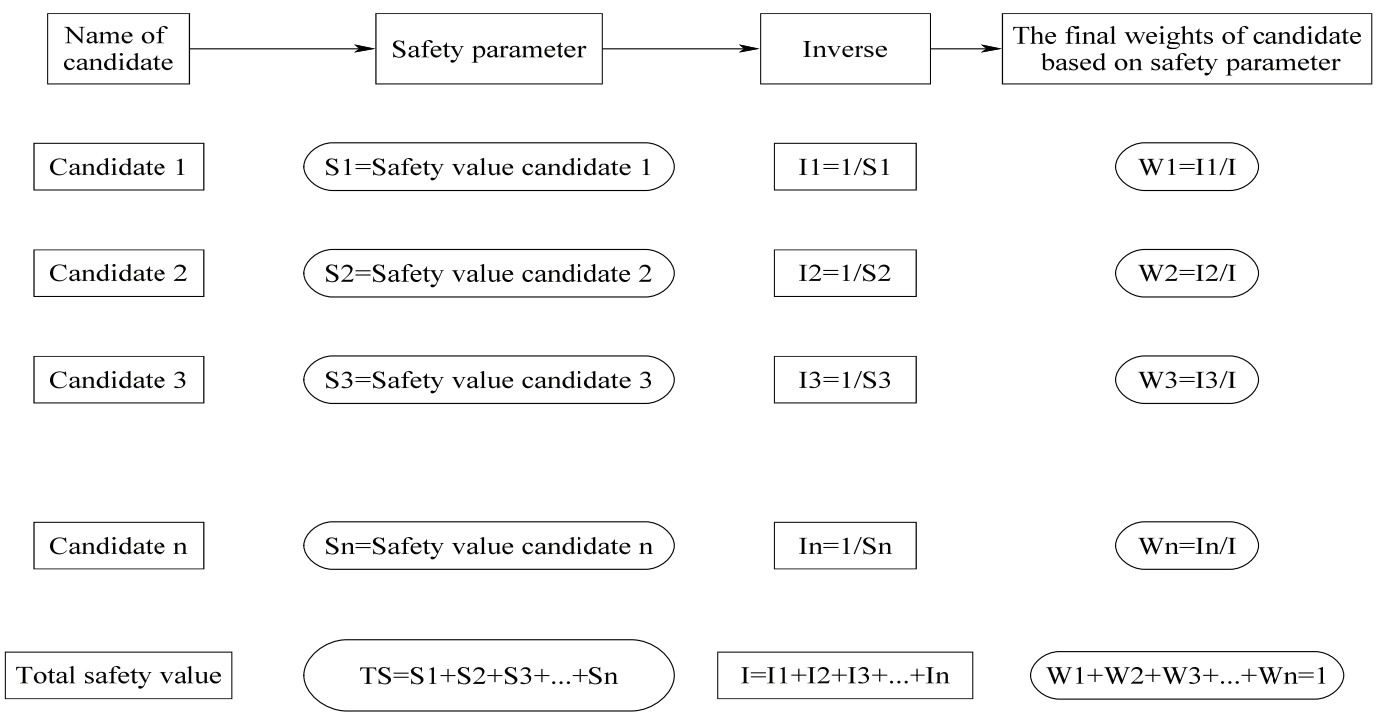

Figure 3 Flowchart of AHP weight for each candidate based on each road safety parameter

These AHP weights are associated with safety parameters, and the safety parameters' weights will be utilized in the process of determining the best candidate through the AHP technique.

\section{Analytic Hierarchy Process for determining the best candidate}

Organizing and analysing complex decisions is facilitated by the Analytic Hierarchy Process (AHP), because it is a structured method. The relative importance of the decision elements or criteria is based on linguistic measures developed by Saaty (1980) on a scale of 1 to 9 semantic differential scoring to give relative rating of two criteria. The scale of differential scoring presumes that the row criterion is of equal or greater importance than the column criterion. The reciprocal values $(1 / 3,1 / 5,1 / 7$, or 1/9) have been used where the row criterion is less important than the column criterion. A decision matrix is constructed by using Saaty's scale and factor attributes are compared pairwise in terms of importance of each criterion/decision element to that of the next level. Once the pairwise matrix is made, Saaty's method of eigenvectors/relative weights are calculated by the following equations [19]:

For a pairwise matrix of elements:

$$
\left[\begin{array}{lll}
C_{11} & C_{12} & C_{13} \\
C_{21} & C_{22} & C_{23} \\
C_{31} & C_{32} & C_{33}
\end{array}\right] .
$$

1. Add the values in each column of the pairwise matrix and divide each element in the matrix by its column total to generate a normalized pairwise matrix

$$
\left[\begin{array}{lll}
X_{11} & X_{12} & X_{13} \\
X_{21} & X_{22} & X_{23} \\
X_{31} & X_{32} & X_{33}
\end{array}\right] X_{i j}=\frac{C_{i j}}{\sum_{i=1}^{n} C_{i j}}
$$

2. Divide the sum of the normalized column of the matrix by the number of criteria $(n)$ to generate a weighted matrix

$\left[\begin{array}{l}W_{11} \\ W_{21} \\ W_{31}\end{array}\right] W_{i j}=\frac{\sum_{j=1}^{n} X_{i j}}{n}$.

3. Consistency Ratio $\left(C_{r}\right)$ should be attained such that $C_{r}<0.10$ and is calculated as follows: 


$$
\left[\begin{array}{lll}
C_{11} & C_{12} & C_{13} \\
C_{21} & C_{22} & C_{23} \\
C_{31} & C_{32} & C_{33}
\end{array}\right] \times\left[\begin{array}{l}
W_{11} \\
W_{21} \\
W_{31}
\end{array}\right]=\left[\begin{array}{l}
C_{v 11} \\
C_{v 21} \\
C_{v 31}
\end{array}\right] \quad \text { Step-I }
$$

Calculation of Consistency Vector is accomplished by dividing the weighted sum vector with the criterion weight as follows:

$$
\begin{aligned}
& C_{v 11}=\frac{1}{W_{11}}\left[C_{11} W_{11}+C_{12} W_{21}+C_{13} W_{31}\right] \\
& C_{v 21}=\frac{1}{W_{21}}\left[C_{21} W_{11}+C_{22} W_{21}+C_{23} W_{31}\right] \text { Step-I } \\
& C_{v 31}=\frac{1}{W_{31}}\left[C_{31} W_{11}+C_{32} W_{21}+C_{33} W_{31}\right]
\end{aligned}
$$

Once the Consistency Vector is calculated, Lambda $(\lambda)$ is calculated by averaging the value of the Consistency Vector. The Consistency Index $(C I)$ provides a measure of deviation from consistency.

$$
C I=\frac{\lambda-n}{n-1}
$$

where $n$ - number of criteria used.
Table 2 Random inconsistency indices $(R I)$ for $N=10$

\begin{tabular}{|c|c|c|c|c|c|c|c|c|c|c|}
\hline$N$ & 1 & 2 & 3 & 4 & 5 & 6 & 7 & 8 & 9 & 10 \\
\hline$R I$ & 0.00 & 0.00 & 0.58 & 0.9 & 1.12 & 1.24 & 1.32 & 1.41 & 1.46 & 1.49 \\
\hline
\end{tabular}

$C_{r}=\frac{C I}{R I}$

This technique is also applied in the current research to determine the best highway candidate among several candidates, with special focus on the cost and safety parameters. The weights of all highway candidates related to every cost and safety parameter as well as the weights of all cost and safety parameters are required for this method. The weights for the present research were obtained using the equations and flowcharts in Figs. 1-3 and Tab. 1 respectively. A simple hierarchy of AHP in terms of the provided cost and safety criteria is shown in Fig. 4.

According to the concept of AHP in the above hierarchy, the first level is called the target, the second level is the criteria and the third level entails alternatives of the provided model. This method can be carried out by Expert Choice software. An example is investigated next, where the proposed methodology is applied to determine the best highway candidate in the case study region. The consistency ratio $\left(C_{r}\right)$ in the current example analysis is 0.007 , and based on the AHP technique definition it is acceptable.

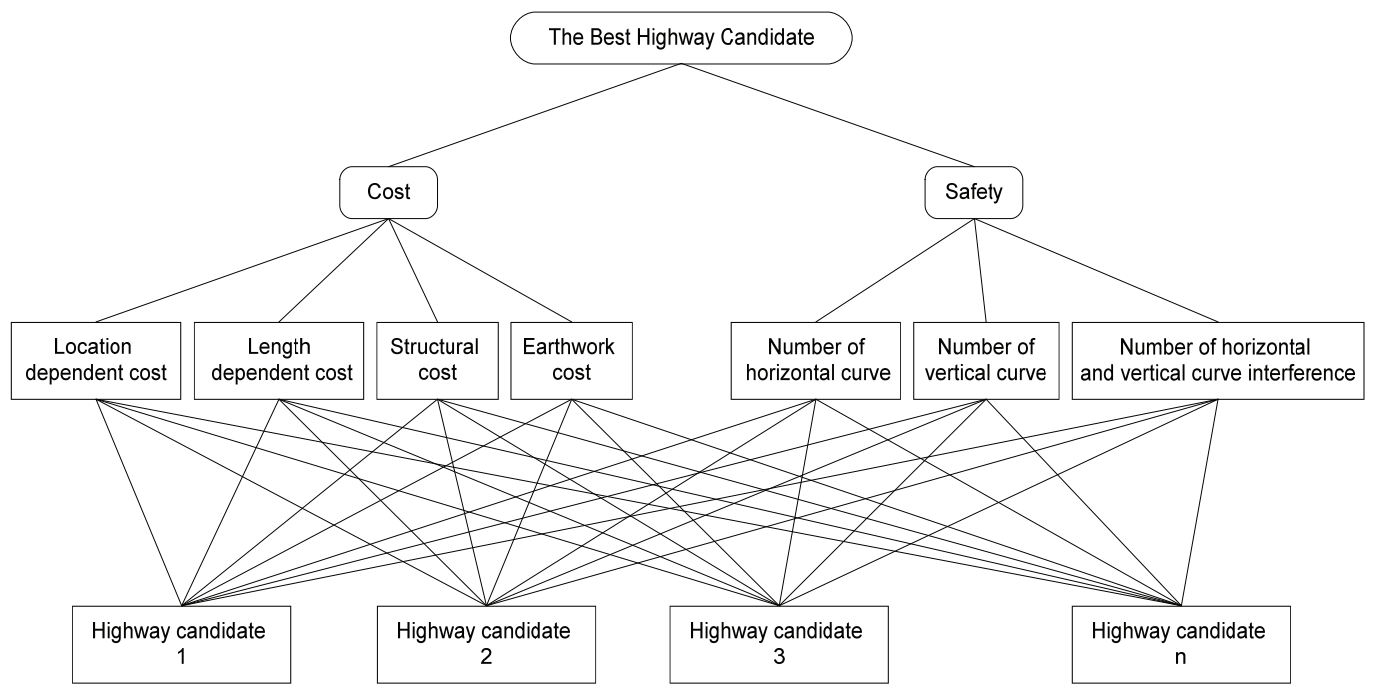

Figure 4 Simple hierarchy of AHP based on the provided cost categories and safety parameters

\section{Example}

An example is provided to demonstrate how the proposed methodology functions and its validation with a real world case study. In this example, three highway candidates are defined between two cities (Qeydar and Zarrin Rood, located in northwest Iran, Fig. 5) based on some constraint parameters (Fig. 6). The geometric specifications of this case study according to cost categories are shown in Tabs. 3-5, which were obtained with ArcGIS and Civil 3D software. The final aim of this example is to simultaneously determine the best candidate in terms of cost and safety criteria.

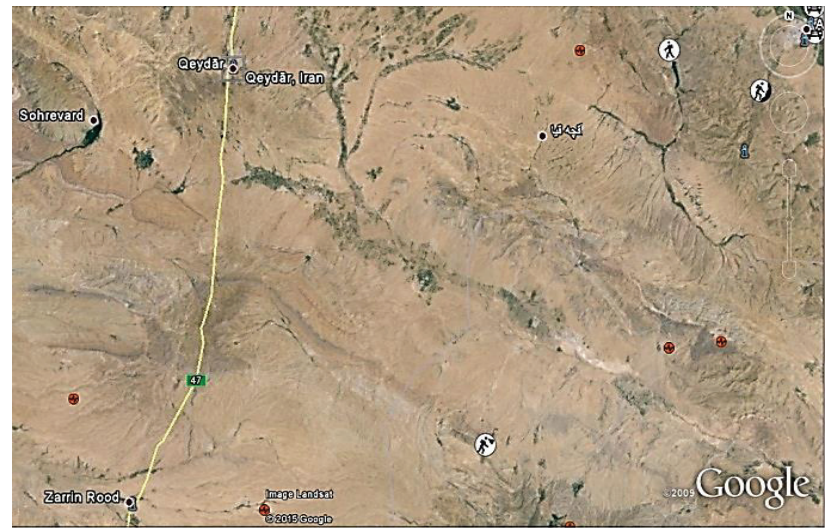

Figure 5 Case study region in northwest Iran 


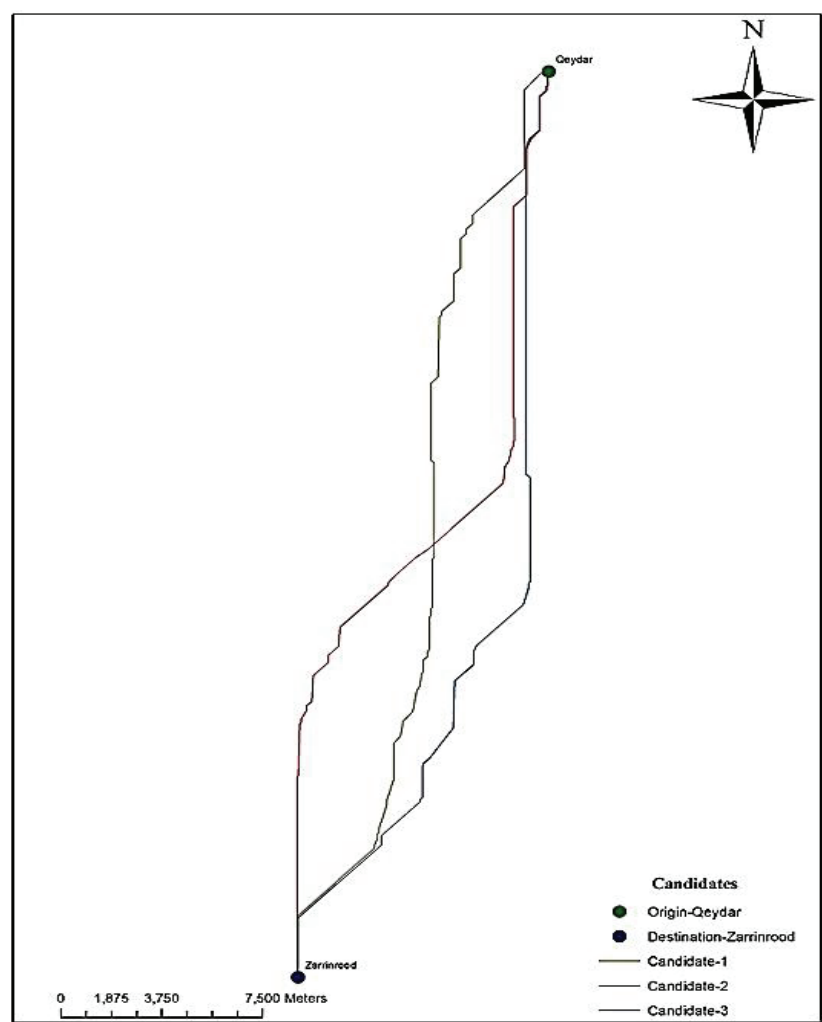

Figure 6 Three highway candidates between Qeydar and Zarrin Rood defined for the current example
Table 3 Unit cost of each cost parameter

\begin{tabular}{|c|l|c|}
\hline $\begin{array}{c}\text { Cost } \\
\text { category }\end{array}$ & \multicolumn{1}{|c|}{ Cost parameter name } & Unit cost (\$) \\
\hline \multirow{4}{*}{$\begin{array}{c}\text { Location } \\
\text { dependent } \\
\text { cost }\end{array}$} & Farming land & 10 \\
\cline { 2 - 3 } & Garden & 50 \\
\cline { 2 - 3 } & National land & 0 \\
\cline { 2 - 3 } & Mix farming land and national land & 5 \\
\hline $\begin{array}{c}\text { Earthwork } \\
\text { cost }\end{array}$ & Cost of cut & 30 \\
\cline { 2 - 3 } $\begin{array}{c}\text { Structural } \\
\text { cost }\end{array}$ & Cost of fill & 3 \\
\cline { 2 - 3 } & Bridge cost based on bridge volume & 1000 \\
\cline { 2 - 3 } & Retaining wall cost & 10000 \\
\hline \multirow{2}{*}{$\begin{array}{c}\text { Length } \\
\text { dependent } \\
\text { cost }\end{array}$} & Pavement cost & 400 \\
\cline { 2 - 3 } & Sign and signal cost & 100 \\
\cline { 2 - 3 } & Safety guards and facility cost & 50 \\
\hline
\end{tabular}

According to the above-mentioned cost specifications of these three highway candidates, the following weights for each highway candidate and cost category are obtained based on the provided methodology.

Tab. 8 shows the specifications of these three highway candidates based on the safety parameters presented in the current research through ArcGIS software.

According to the above-mentioned safety specifications of the three highway candidates, the following safety weights for each highway candidate are obtained according to the provided methodology.

Table 4 Location properties obtained with ArcGIS software for the three candidates

\begin{tabular}{|c|c|c|c|c|c|c|c|c|}
\hline \multicolumn{3}{|c|}{ Candidate-1 } & \multicolumn{3}{|l|}{ Candidate-2 } & \multicolumn{3}{|l|}{ Candidate-3 } \\
\hline Landuse & Alfa & $\begin{array}{l}\text { Total } \\
\text { Area } \\
\left(\mathrm{m}^{2}\right)\end{array}$ & Landuse & Alfa & $\begin{array}{l}\text { Total } \\
\text { Area } \\
\left(\mathrm{m}^{2}\right)\end{array}$ & Landuse & Alfa & $\begin{array}{l}\text { Total } \\
\text { Area } \\
\left(\mathrm{m}^{2}\right)\end{array}$ \\
\hline Farming land & 1.00 & 102600 & Mix farming land and garden & 1.00 & 152000 & Mix farming land and garden & 1.00 & 152000 \\
\hline Garden & 1.00 & 49400 & Mix farming land and garden & 0.85 & 19000 & Mix farming land and garden & 0.85 & 15200 \\
\hline Garden & 0.85 & 15200 & Farming land & 0.85 & 209000 & Farming land & 0.85 & 212800 \\
\hline Farming land & 0.85 & 212800 & Farming land & 0.75 & 95000 & Farming land & 0.75 & 68400 \\
\hline Farming land & 0.75 & 604200 & Mix farming land and garden & 0.75 & 83600 & Mix farming land and garden & 0.75 & 110200 \\
\hline $\begin{array}{l}\text { Mix farming land } \\
\text { and national land }\end{array}$ & 0.75 & 592800 & Farming land & 0.75 & 1045000 & Farming land & 0.75 & 900600 \\
\hline Farming land & 0.75 & 577600 & $\begin{array}{l}\text { Mix farming land and national } \\
\text { land }\end{array}$ & 0.75 & 433200 & $\begin{array}{l}\text { Mix farming land and national } \\
\text { land }\end{array}$ & 0.75 & 737200 \\
\hline Farming land & 0.75 & 125400 & National land & 0.75 & 171000 & Farming land & 0.75 & 630800 \\
\hline Farming land & 0.75 & 315400 & $\begin{array}{l}\text { Mix farming land and national } \\
\text { land }\end{array}$ & 0.75 & 144400 & Farming land & 0.85 & 216600 \\
\hline $\begin{array}{l}\text { Mix farming } \\
\text { land and garden }\end{array}$ & 0.75 & 76000 & Farming land & 0.75 & 478800 & Garden & 0.85 & 11400 \\
\hline Farming land & 0.75 & 152000 & Farming land & 0.85 & 212800 & Garden & 1.00 & 53200 \\
\hline Farming land & 0.85 & 155800 & Garden & 0.85 & 15200 & Farming land & 1.00 & 98800 \\
\hline $\begin{array}{l}\text { Mix farming land } \\
\text { and garden }\end{array}$ & 0.85 & 72200 & Garden & 1.00 & 49400 & - & - & - \\
\hline $\begin{array}{l}\text { Mix farming land } \\
\text { and garden }\end{array}$ & 1.00 & 57,000 & Farming land & 1.00 & 102600 & - & - & - \\
\hline National land & 1.00 & 11400 & - & - & - & - & - & - \\
\hline $\begin{array}{l}\text { Mix farming land } \\
\text { and garden }\end{array}$ & 1.00 & 83600 & - & - & - & - & - & - \\
\hline
\end{tabular}

Table 5 Specifications of each highway candidate extracted from Civil 3D software

\begin{tabular}{|c|c|c|c|c|c|c|}
\hline $\begin{array}{l}\text { Name of } \\
\text { Candidate }\end{array}$ & $\begin{array}{l}\text { Total length } \\
(\mathrm{m})\end{array}$ & $\begin{array}{l}\text { Total bridge } \\
\text { length }(\mathrm{m})\end{array}$ & $\begin{array}{l}\text { Total tunnel } \\
\text { length }(\mathrm{m})\end{array}$ & $\begin{array}{c}\text { Total retaining wall } \\
\text { area }\left(\mathrm{m}^{2}\right)\end{array}$ & $\begin{array}{l}\text { Total cut volume } \\
\left(\mathrm{m}^{3}\right)\end{array}$ & $\begin{array}{c}\text { Total fill } \\
\text { volume }\left(\mathrm{m}^{3}\right)\end{array}$ \\
\hline Candidate-1 & 42168.3124 & 143.75 & 0 & 0 & 5739088.36 & 6477345.82 \\
\hline Candidate- 2 & 42263.5101 & 122.85 & 0 & 0 & 2563764.95 & 3619957.98 \\
\hline Candidate-3 & 42243.776 & 74.7 & 0 & 0 & 1012294.27 & 1132571.51 \\
\hline
\end{tabular}


Table 6 Final weights of each highway candidate based on each cost category provided

\begin{tabular}{|c|c|c|c|c|}
\hline Candidate Name & Location dependent cost & Earthwork cost & Length dependent cost & Structural cost \\
\hline Candidate-1 & 0.3252 & 0.1154 & 0.3338 & 0.2442 \\
\hline Candidate-2 & 0.3432 & 0.2278 & 0.3330 & 0.2858 \\
\hline Candidate-3 & 0.3316 & 0.6568 & 0.3332 & 0.47 \\
\hline
\end{tabular}

Table 7 Final weights of each cost category

\begin{tabular}{|c|c|c|c|c|}
\hline Cost category & Location dependent cost & Earthwork cost & Length dependent cost & Structural cost \\
\hline Final weight & 0.5099 & 0.3511 & 0.1371 & 0.0019 \\
\hline
\end{tabular}

Table 8 Specifications of each highway candidate based on the safety parameters provided

\begin{tabular}{|c|c|c|c|}
\hline Name of Candidate & Number of horizontal curve & Number of vertical curve & Number of horizontal and vertical curve interference \\
\hline Candidate-1 & 47 & 55 & 17 \\
\hline Candidate-2 & 37 & 64 & 23 \\
\hline Candidate-3 & 27 & 49 & 17 \\
\hline
\end{tabular}

Table 9 Final weights of each highway candidate based on each safety parameter

\begin{tabular}{|c|c|c|c|}
\hline Name of Candidate & Number of horizontal and vertical curve interference & Number of horizontal curve & Number of vertical curve \\
\hline Candidate-1 & 0.3651 & 0.2493 & 0.3354 \\
\hline Candidate-2 & 0.2698 & 0.3167 & 0.2882 \\
\hline Candidate-3 & 0.3651 & 0.434 & 0.3764 \\
\hline
\end{tabular}

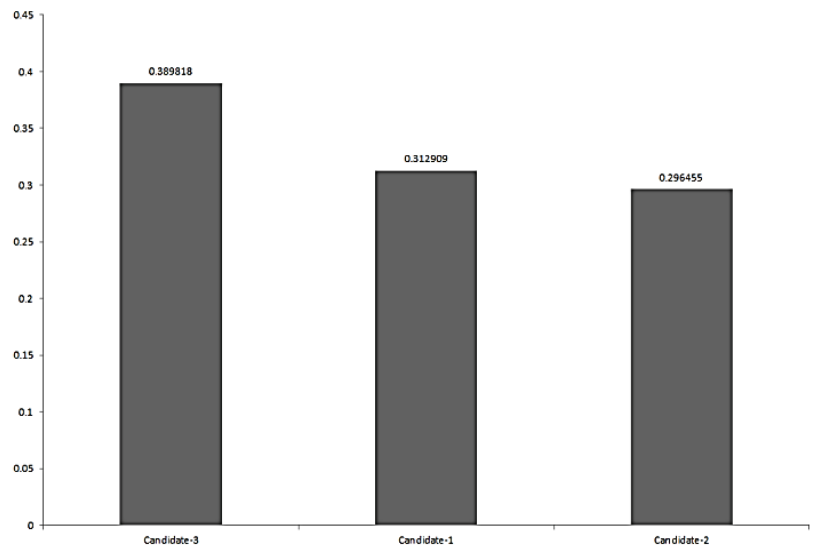

Figure 7 Final AHP weights of each highway candidate based on the provided cost and safety parameters
The final weights of all safety parameters relative to each other are obtained from the questionnaire expressed in Tab. 1.

After determining the final weights of the highway candidates and of all cost and safety parameters, all weights found are input to the Expert Choice software, and the final weights of each highway candidate based on cost and safety are the output.

The final result is illustrated as a bar chart in Fig. 7, and it signifies that the best highway candidate can satisfy all cost and safety parameters simultaneously.

Fig. 8 displays the sensitivity graph of three highway candidates in terms of cost and safety parameters. In this graph three candidates are considered based on safety parameters, cost parameters and overall with each other.

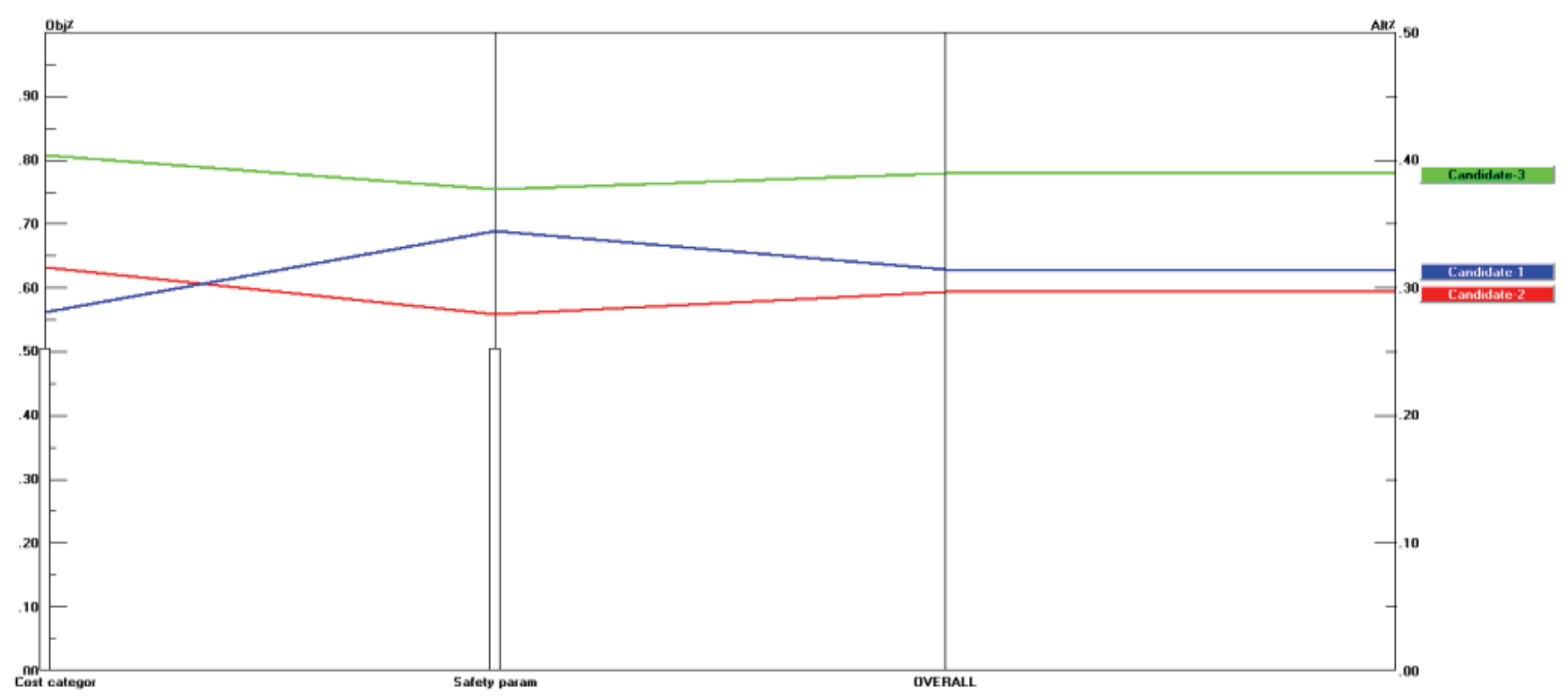

Figure 8 Sensitivity graph of highway candidates based on their weights

\section{Conclusion}

In this paper, an attempt is made to develop a multicriteria analysis methodology to determine the best highway candidate, with specific focus on cost and safety parameters. The multi-criteria analysis methodology is based upon the analytical hierarchy process technique, which systematically determines the best highway candidate according to the effect of each parameter of the defined highway safety and costs. Regarding highway 
indirect costs in the current research, four categories are expanded and organised, including: length-dependent cost, earthwork cost, location-dependent cost and structural cost. In terms of highway safety in the current work, the three parameters investigated are the number of horizontal and vertical curve interferences, the number of horizontal curves and the number of vertical curves.

All cost and safety parameters presented in this research are basically deemed comparable values to be used in the provided methodology for determining the best highway candidate. The final highway candidate determined as the best candidate through the methodology presented can meet all related parameters in determining the optimal highway candidate simultaneously. Considering all parameters related to optimization concurrently is an advantage of proposed methodology because it solves the weakness of the previous methodologies for highway optimization as mentioned in introduction. To use the proposed methodology in this research a wide volume of information is needed which can be considered as a weakness of the proposed methodology. This methodology is employed for defining the best highway candidate in the conditions applicable to Iran and it can be upgraded for other territories.

\section{$7 \quad$ Reference}

[1] Howard, B.; Bramnick, Z.; Shaw, J. Optimum curvature principle in highway routing. // Transportation research board of the national academics. (1969), pp. 236-241.

[2] Turner, A. K.; Miles, R. D. The GCARS system: A computer-assisted method of regional route location. Highway Research Board publishing company, Washington, 1971.

[3] Hogan, J. Experience with OPTLOC optimum location of highways by computer. // In PTRC Seminar Proceedings on Cost Model and Optimization in Highway. London, 1973.

[4] Jong, J. C. Optimizing highway alignments with genetic algorithms, 1998. (Doctoral dissertation, research directed by Dept. of Civil Engineering.University of Maryland, College Park, Md.).

[5] Jha, M. K. A Geographic Information Systems-Based model For Highway Design Optimization, 2000. (Doctoral dissertation, research directed by Dept. of Civil Engineering.University of Maryland, College Park, Md.).

[6] Habibian, M. Identify the different components of the twolane two-way roads intercity in safety using a dissimilar approach. // Transportation Engineering Journal, (2012). pp. 293-303.

[7] Saffarzadeh, M. P. M. Modeling of Determine Road Safety Index. // Civil Journal of Modarres University, 2008.

[8] President, P.a.C.D.o.S.o.I., Regulations geometric design of Iran roads, 2012: Iran. p. 422.

[9] Maji, A. Multi-objective highway alignment optimization, 2008. (Doctoral dissertation, research directed by Dept. of Civil Engineering.Moregan state of university).

[10] Van Bergeijk, P. A.; Murshed, S. The Relation between Land Price and Distance to CBD in Bekasi. 2012. (In partial fulfillment of the requirements for obtaining the degree of masters of arts in development studies)

[11] Haughwout, A.; Orr, J.; Bedoll, D. The price of land in the New York metropolitan area. // Current Issues in Economics and Finance, 14, 3(2008).

[12] Jha, M. K.; Schonfeld, P. A highway alignment optimization model using geographic information systems.
// Transportation Research Part A: Policy and Practice. 38, 6(2004), pp. 455-481. https://doi.org/10.1016/j.tra.2004.04.001

[13] Gupta, R.; Jain, R. Effect of Certain Roadway Characteristics on Accident Rates for Two-Lane, Two-Way Roads in Connecticut (Abridgment). // Transportation Research Record. (1975), p. 541.

[14] Walmsley, D. A.; Summersgill, I. The relationship between road layout and accidents on modern rural trunk roads. // Transportation research board of the national academics. (1998), pp. 62.

[15] Ahadi, M. R. Effect of Geometric Design Parameters to Improve Safety and Accidents Reduction (Case Study: Sari - Kiasar Corridor). // Journal of Safety Promotion and Injury Prevention. 1, 3(2013), pp. 13.

[16] Anastasopoulos, P.C.; Mannering, F. L. A note on modeling vehicle accident frequencies with randomparameters count models. // Accident Analysis \& Prevention. 41, 1(2009), pp. 153-159. https://doi.org/10.1016/j.aap.2008.10.005

[17] Elvik, R. How much do road accidents cost the national economy? // Accident Analysis \& Prevention. 32, 6(2000), pp. 849-851. https://doi.org/10.1016/S0001-4575(00)00015-4

[18] Lamm, R.; Psarianos, B.; Cafiso, S. Safety evaluation process for two-lane rural roads: A 10-year review. // Transportation Research Record: Journal of the Transportation Research Board. 1791, 1(2002), pp. 51-59. https://doi.org/10.3141/1796-06

[19] Sadasivuni, R. et al. A transportation corridor case study for multi-criteria decision analysis. // in American Society of Photogrammetry and remote Sensing Annual Conference. 2009.

\section{Authors' addresses}

Seyed Mahdi Sajjadi, PhD

Department of Civil Engineering, Zanjan Branch, Islamic Azad University,

Zanjan, Iran

s.mehdi.sajjadi@gmail.com

Seyyed Amir Hossien Beheshty, PhD

Department of Civil Engineering, Zanjan Branch, Islamic Azad University, Zanjan, Iran

a_h_beheshti@yahoo.com 